Akreditasi KEMENRISTEKDIKTI, Nomor: 148/M/KPT/2020
http://iurnal.stkippersada.ac.id/jurnal/index.php/VOX

\title{
EVALUASI RENCANA PELAKSANAAN PEMBELAJARAN MATA PELAJARAN IPA (BIOLOGI) BERBASIS SCIENTIFIC APPROACH KELAS VIII DI SMP MUHAMMADIYAH SE-KECAMATAN KALASAN
}

\author{
Azkia Hasna Nuha Imana ${ }^{1}$, \& Nani Aprilia ${ }^{2}$ \\ ${ }^{1,2}$ Fakultas Keguruan dan Ilmu Pendidikan, Universitas Ahmad Dahlan \\ Email:azkia1600008021@webmail.uad.ac.id ${ }^{1}$, naniaprilia@pbio.uad.ac.id ${ }^{2}$
}

INFO ARTIKEL
Riwayat Artikel:
$\begin{array}{ll}\text { Menerima } & : 06 \text { Juni } 2020 \\ \text { Revisi } & : 14 \text { Oktober } 2020 \\ \text { Diterima } & : 23 \text { Oktober } 2020\end{array}$

\section{Kata Kunci:}

Evaluasi, RPP, Scientific Approach

Keywords:

Evaluation, RPP,

Scientific Approach

\section{Korespondensi:}

Azkia Hasna Nuha Imana Fakultas Keguruan dan Ilmu Pendidikan, Universitas Ahmad Dahlan Email:

Azkia1600008021@webmail.u ad.ac.id

\section{ABSTRAK}

Latar belakang dalam penelitian ini adalah 50\% guru belum memiliki Rencana Pelaksanaan Pembelajaran (RPP) untuk mengajar, RPP yang ada di sekolah belum sesuai dengan kelengkapan Permendikbud No. 22 Tahun 2016 tentang Standar Proses, RPP yang dibuat guru belum sesuai dengan ketercukupan komponen Scientific Approach, dan RPP yang disusun tidak terlaksana dalam proses pembelajaran. Penelitian ini bertujuan untuk mengevaluasi Rencana Pelaksanaan Pembelajaran (RPP) Mata Pelajaran IPA (Biologi) Berbasis Scientific Approach Kelas VIII di SMP Muhammadiyah Se-Kecamatan Kalasan. Penelitian ini merupakan penelitian evaluasi. Objek penelitian ini adalah RPP mata pelajaran IPA (Biologi) yang terdiri dari RPP selama satu tahun pada kelas VIII di SMP Muhammadiyah Se-Kecamatan Kalasan. Teknik pengumpulan data dengan cara observasi, dengan instrumen penelitian berupa lembar observasi berupa daftar checklist. Data yang diperoleh dianalisis secara deskriptif kuantitatif, dengan membandingkan hasil penelitian dengan kriteria yang telah ditentukan. Hasil penelitian menunjukkan bahwa : (1) kesesuaian komponen rencana pelaksanaan pembelajaran (RPP) mata pelajaran IPA (Biologi) di SMP Muhammadiyah Se-Kecamatan Kalasan yang telah memenuhi komponen Permendikbud termasuk kedalam kategori baik, dengan persentase sebesar 91,04\%; (2) ketercukupan komponen Scientific Approach pada rencana pelaksanaan pembelajaran (RPP) mata pelajaran IPA (Biologi) di SMP Muhammadiyah Se-Kecamatan Kalasan termasuk kedalam kategori baik, dengan persentase sebesar $88,21 \%$.

\section{ABSTRACT}

The background in this study is that 50\% of teachers do not yet have a lesson plan to teach, the lesson plan in schools is not in accordance with the requirements of Permendikbud No. 22 of 2016 concerning Process Standards, lesson plans made by teachers are not in accordance with the adequacy of the Scientific Approach components, and lesson plans made are not implemented in the learning process. Natural Sciences (Biology) Subjects RPP Based on Scientific Approaches Class VIII at Muhammadiyah Yunior High Schools in Kalasan District. This research is an evaluation research. The object of this research is the RPP of Natural Sciences (Biology) which consists of one year RPP in class VIII at Muhammadiyah Yunior High Schools in Kalasan District. Data collection techniques by observation, with the research instrument in the form of an observation sheet containing a checklist. The data obtained were analyzed descriptively quantitatively, by comparing the results of research with predetermined criteria. The results showed: (1) the suitability of the components of the learning plan (RPP) of Natural Sciences (Biology) in Muhammadiyah Yunior High Schools in Kalasan District that had fulfilled the Permendikbud component included in the good category, with a contribution of $91.04 \%$; (2) the adequacy of the Scientific Approach component in the learning plan (RPP) of Natural Sciences (Biology) in the Muhammadiyah Yunior High Schools in Kalasan District is included in the good category, with a contribution of $88.21 \%$. 


\section{PENDAHULUAN}

Kurikulum 2013 adalah kurikulum berbasis kompetensi yang pernah digagas dalam rintisan Kurikulum Berbasis Kompetensi (KBK) 2004, tetapi belum terselesaikan karena desakan untuk segera mengimplementasikan Kurikulum Tingkat Satuan Pendidikan 2006. Kurikulum 2013 menekankan pada dimensi pedagogik modern dalam pembelajaran, yaitu menggunakan pendekatan ilmiah (Shoimin, 2014).

Adanya pergantian kurikulum 2013, istilah pendekatan ilmiah atau Scientific Approach pada pelaksanaan pembelajaran menjadi bahan pembahasan yang menarik perhatian para pendidik. Hal ini sejalan dengan penelitian (Paraniti \& Noviyanti, 2019) yang menyatakan bahwa implementasi K-13 dikatakan sudah sesuai karena sudah sesuai dengan karakteristik K-13 yang menggunakan pendekatan saintifik dalam proses pembelajarannya. Penerapan Scientific Approach menjadi tantangan guru melalui pengembangan aktivitas siswa yaitu mengamati, menanya, mengumpulkan informasi, mengasosiasikan /menalar, dan mengkomunikasikan (Hosnan, 2014).

Pendekatan pembelajaran yang ilmiah (Scientific Approach) merupakan bagian dari pendekatan pedagogis pada pelaksanaan pembelajaran dalam kelas yang melandasi penerapan metode ilmiah (Warso, 2014). Siswa dikatakan belajar ketika terjadi perubahan yang mencakup aspek kognitif, afektif, dan psikomotorik dalam dirinya sebagai hasil dari pengalaman belajarnya.

Scientific Approach tidak hanya memandang hasil belajar sebagai hasil akhir, namun proses pembelajaran dipandang sangat penting dalam kegiatan pembelajaran. Oleh karena itu, Scientific Approach menekankan pada keterampilan proses. Model pembelajaran berbasis peningkatan peningkatan peningkatan pembelajaran yang mengintegrasikan keterampilan proses sains kedalam sistem penyajian materi secara terpadu. Model ini menekankan pada proses pencarian pengetahuan dari pada transfer pengetahuan, peserta didik dipandang sebagai subjek belajar yang perlu dilibatkan secara aktif dalam proses pembelajaran, guru hanyalah seorang fasilitator yang membimbing dan mengkoordinasikan kegiatan belajar (Ibrahim, 2010).

Penting bagi guru IPA/biologi untuk merencanakan apa yang ingin diajarkannya dalam sebuah rencana pelaksanaan pembelajaran (RPP). RPP yang digunakan guru sebagai pedoman harusnya disusun oleh guru itu sendiri dan benar-benar dijadikan sebagai pedoman oleh guru dalam pelaksanaan pembelajaran. Dengan demikian, keberadaan RPP diharapkan akan memperlancar, meningkatkan, mengefektifkan, serta mengoptimalkan mutu proses pembelajaran guna pencapaian tujuan-tujuan pembelajaran.

Penelitian ini dilakukan di SMP Muhammadiyah Se-Kecamatan Kalasan yang terdiri atas dua sekolah yaitu SMP Muhammadiyah 1 Kalasan dan SMP Muhammadiyah 2 Kalasan. Berdasarkan observasi di SMP Muhammadiyah 2 Kalasan pada tanggal 02 Agustus - 03 September 2019, bahwa 50\% guru belum memiliki RPP untuk mengajar, guru membuat RPP hanya sebagai formalitas saja sebagai bentuk pertanggungjawaban kegiatan pembelajaran pada saat pengawas sekolah visit. Berdasarkan hasil wawancara dengan guru IPA (Biologi) di SMP Muhammadiyah 2 Kalasan pada tanggal 4 Oktober 2019, guru mengemukakan bahwa untuk mata pelajaran IPA (Biologi) sebenarnya lebih ideal dengan menggunakan Scientific Approach dengan aktivitas pembelajaran yaitu mengamati, menanya, mengumpulkan 
informasi, menalar / mengasosiasikan, dan mengkomunikasikan, sehingga siswa dapat terlibat langsung dalam pembelajaran. Namun, karena Kurikulum 2013 baru diterapkan di SMP Muhammadiyah Se-Kecamatan Kalasan menyebabkan guru sedikit kesulitan dalam pembuatan RPP. Pada kurikulum sebelumnya yaitu Kurikulum Tingkat Satuan Pendidikan (KTSP) masih menggunakan tahapan elaborasi, eksplorasi dan konfirmasi (EEK) dalam tahapan pembelajaran, sedangkan Kurikulum 2013 menuntut guru untuk membuat langkah-langkah pembelajaran dengan menggunakan Scientific Approach yaitu mengamati, menanya, mengumpulkan informasi, menalar /mengasosiasikan, dan mengkomunikasikan. Selain itu RPP yang disusun guru sering kali tidak terlaksana ketika proses pembelajaran berlangsung.

Berdasarkan hasil wawancara dengan guru IPA (Biologi) di SMP Muhammadiyah 1 Kalasan pada tanggal 3 Oktober 2019, diperoleh informasi yang sama dengan SMP Muhammadiyah 2 Kalasan, guru mengakui bahwasannya pada kurikulum 2013 mengajarkan IPA (Biologi) lebih cocok dengan menggunakan Scientific Approach karena dengan menggunakan Scientific Approach siswa dapat terlibat langsung dalam pembelajaran. Hal ini sejalan dengan penelitian (Susilo, 2016) yang mengatakan bahwa pendekatan saintifik (scientific approach) tepat diterapkan dalam pembelajaran IPA khususnya biologi, karena pendekatan saintik (scientific approach) memberikan pemahaman kepada peserta didik dalam mengenal, memahami berbagai materi menggunakan metode ilmiah. Namun, selama mengajar guru di SMP Muhammadiyah 1 Kalasan tersebut masih menggunakan RPP yang dibuat oleh Musyawarah Guru Mata Pelajaran (MGMP) Kabupaten, sehingga menyebabkan guru sedikit kesulitan didalam proses pembelajaran didalam kelas karena guru mengacu pada RPP yang dibuat MGMP yang sebagian besar belum sesuai dengan kelengkapan (Permendikbud, 2016), dan komponen RPP yang belum sesuai dengan ketercukupan Scientific Approach.

Berdasarkan latar belakang masalah terkait dengan ketercukupan Scientific Approach, alasan peneliti melakukan penelitian di SMP Muhammadiyah Se-Kecamatan Kalasan karena mengingat SMP Muhammadiyah di Kecamatan Kalasan baru dua tahun ini melaksanakan pembelajaran dengan menggunakan Kurikulum 2013 berbasis Scientific Approach sehingga masih adanya kesulitan dalam penyusunan RPP di sekolah. Hal ini sejalan dengan penelitian (Suciati \& Astuti, 2016) yang menyebutkan bahwa mahasiswa yang sebelumnya lebih memahami format RPP KTSP perlu belajar kembali tentang perubahan kurikulum yang terjadi lalu menuangkannya dalam format RPP kurikulum 2013 yang bisa dikatakan baru diterapkan dengan menggunakan pendekatan ilmiah/sanitifk. Mengingat pentingnya rencana pelaksanaan pembelajaran (RPP) dalam suatu proses pembelajaran dan belum diadakannya evaluasi tentang rencana pelaksanaan pembelajaran (RPP), maka peneliti mengkaji dan meneliti tentang evaluasi rencana pelaksanaan pembelajaran di sekolah SMP Muhammadiyah Se-Kecamatan Kalasan pada mata pelajaran IPA (Biologi) untuk mengetahui gambaran rencana pelaksanaan pembelajaran (RPP) yang dibuat guru kedalam mata pelajaran IPA (Biologi), dalam bentuk skripsi yang berjudul: "Evaluasi Rencana Pelaksanaan Pembelajaran (RPP) Mata Pelajaran IPA (Biologi) Berbasis Scientific Approach Kelas VIII di SMP Muhammadiyah Se-Kecamatan Kalasan. 


\section{METODE PENELITIAN}

Penelitian ini termasuk penelitian evaluasi. Penelitian evaluasi menurut (Arikunto, 2010) menuntut adanya persyaratan yang harus dipenuhi dengan adanya kriteria, tolak ukur, atau standar, yang digunakan sebagai pembanding bagi data yang diperoleh, setelah data diperoleh, setelah data tersebut diolah dan merupakan kondisi nyata dari objek yang diteliti. Evaluasi digunakan untuk memperoleh informasi mengenai rencana pelaksanaan pembelajaran (RPP) guru mata pelajaran IPA (Biologi) di SMP Muhammadiyah Se-Kecamatan Kalasan, sehingga dapat dijadikan sebagai acuan dalam pembuatan RPP sesuai dengan kriteria sehingga dapat menunjang proses pembelajaran yang terencana dan terarah sesuai dengan tujuan pendidikan.

Objek dalam penelitian ini adalah RPP mata pelajaran IPA (Biologi) yang terdiri dari RPP selama satu tahun pada kelas VIII di SMP Muhammadiyah Se-Kecamatan Kalasan yang terdiri dari dua sekolah yaitu SMP SMP Muhammadiyah 1 Kalasan dan SMP Muhammadiyah 2 Kalasan. Pemilihan kelas VIII dikarenakan untuk Kurikulum 2013 di SMP Muhammadiyah Se-Kecamatan Kalasan baru diterapkan sehingga untuk kelas VIII baru mengalami perubahan kurikulum 2013 selama dua semester sehingga dapat dijadikan sebagai objek penelitian untuk melihat apakah Scientific Approach sudah diterapkan dalam RPP atau belum.

Teknik pengumpulan data yang digunakan dalam penelitian evaluasi rencana pelaksanaan pembelajaran (RPP) guru mata pelajaran IPA (Biologi) berbasis Scientific Approach adalah teknik observasi. Teknik ini digunakan untuk mengetahui gambaran rencana pelaksanaan pembelajaran berupa RPP IPA (Biologi). Pada penelitian ini, observasi dan analisis RPP dilakukan tiga orang pengamat (observer), pengamat melakukan observasi dengan cara mengamati dan menganalisis RPP menggunakan lembar observasi sebagai instrumen penelitian.

Instrumen pengumpulan data yang digunakan pada penelitian ini merupakan instrumen tunggal/hanya menggunakan satu instrumen saja yaitu lembar observasi sebagai alat evaluasi. Lembar observasi yang digunakan untuk mengevaluasi RPP yang dilakukan oleh observer berupa daftar checklist mengenai rencana pelaksanaan pembelajaran (RPP) yang dibuat guru IPA (Biologi). Skala pengukuran yang digunakan pada penelitian ini adalah menggunakan skala Likert. Menurut (Sukardi, 2011) skala Likert digunakan oleh para peneliti guna mengukur persepsi atau sikap seseorang.

Data hasil observasi RPP mata pelajaran IPA (Biologi) berbasis Scientific Approach di SMP Muhammadiyah Se-Kecamatan Kalasan dianalisis secara deskriptif kuantitatif dengan cara membandingkan rerata perolehan skor empiris pada tiap variabel yang diukur dengan kriteria penilaian yang telah ditentukan. Analisis data hasil observasi pada rencana pelaksanaan pembelajaran (RPP) mata pelajaran IPA (Biologi) berbasis Scientific Approach di SMP Muhammadiyah SeKecamatan Kalasan menggunakan lembar observasi (pengamatan). Data dianalisis dengan menggunakan rumus menurut (Sugiono, 2012):

$$
\mathrm{P}=\frac{\sum s k o r}{N} \times 100 \%
$$

Keterangan :

$\begin{array}{ll}\mathrm{P} & : \text { Angka persen } \\ \text { Nskor } & \text { : Jumlah skor yang diperoleh } \\ \mathrm{N} & \text { : Skor ideal untuk seluruh item }\end{array}$




\section{HASIL DAN PEMBAHASAN}

\section{Hasil}

Tabel 1. Hasil Keseluruhan Evaluasi Rencana Pelaksanaan Pembelajaran (RPP) SMP Muhammadiyah Se-Kecamatan Kalasan

\begin{tabular}{|c|c|c|c|c|}
\hline \multirow{2}{*}{ RPP ke- } & \multicolumn{2}{|c|}{$\begin{array}{c}\text { SMP Muh 1 } \\
\text { Kalasan }\end{array}$} & \multicolumn{2}{c|}{$\begin{array}{c}\text { SMP Muh 2 } \\
\text { Kalasan }\end{array}$} \\
\cline { 2 - 5 } & Nilai & Kategori & Nilai & Kategori \\
\hline RPP 1 & $88,41 \%$ & Baik & $95,65 \%$ & Baik \\
\hline RPP 2 & $86,23 \%$ & Baik & $95,28 \%$ & Baik \\
\hline RPP 3 & $85,51 \%$ & Baik & $94,56 \%$ & Baik \\
\hline RPP 4 & $85,14 \%$ & Baik & $94,56 \%$ & Baik \\
\hline RPP 5 & $86,59 \%$ & Baik & $94,20 \%$ & Baik \\
\hline RPP 6 & $89,49 \%$ & Baik & $95,29 \%$ & Baik \\
\hline RPP 7 & $88,04 \%$ & Baik & $95,65 \%$ & Baik \\
\hline Rata-rata & \multicolumn{4}{|c|}{ 91,04 \% } \\
\hline Kategori & \multicolumn{4}{|c|}{ Baik } \\
\hline
\end{tabular}

Hasil yang diperoleh dari evaluasi rencana pelaksanaan pembelajaran (RPP) yang terdiri dari 14 RPP, dengan memilih 7 materi IPA (Biologi) selama satu tahun dari dua orang guru mata pelajaran IPA (Biologi) kelas VIII di SMP Muhammadiyah Se-Kecamatan Kalasan yaitu SMP Muhammadiyah 1 Kalasan dan SMP Muhammadiyah 2 Kalasan tahun pelajaran 2019/2020 menunjukkan hasil yaitu pada kategori baik berdasarkan Permendikbud No.22 Tahun 2016 tentang Standar Proses . Rata-rata nilai akhir dari semua RPP yang telah dievaluasi mencapai angka $91,04 \%$. Berikut ini tabel hasil nilai akhir keseluruhan evaluasi rencana pelaksanaan pembelajaran (RPP) mata pelajaran IPA (Biologi).

Tabel 2. Hasil Evaluasi Ketercukupan Komponen Scientific Approach dari Keseluruhan RPP di SMP Muhammadiyah SeKecamatan Kalasan

\begin{tabular}{|c|c|c|c|c|}
\hline \multirow{2}{*}{ RPP ke- } & \multicolumn{2}{|c|}{$\begin{array}{c}\text { SMP Muh 1 } \\
\text { Kalasan }\end{array}$} & \multicolumn{2}{c|}{$\begin{array}{c}\text { SMP Muh 2 } \\
\text { Kalasan }\end{array}$} \\
\cline { 2 - 5 } & Nilai & Kategori & Nilai & Kategori \\
\hline RPP 1 & $93,33 \%$ & Baik & $91,66 \%$ & Baik \\
\hline RPP 2 & $80,00 \%$ & Baik & $91,66 \%$ & Baik \\
\hline RPP 3 & $85,00 \%$ & Baik & $93,33 \%$ & Baik \\
\hline RPP 4 & $71,66 \%$ & Baik & $93,33 \%$ & Baik \\
\hline RPP 5 & $85,00 \%$ & Baik & $91,66 \%$ & Baik \\
\hline RPP 6 & $80,00 \%$ & Baik & $93,33 \%$ & Baik \\
\hline RPP 7 & $91,66 \%$ & Baik & $93,33 \%$ & Baik \\
\hline Rata-rata & \multicolumn{5}{|c|}{$\mathbf{8 8 , 2 1 ~ \% ~}$} \\
\hline Kategori & \multicolumn{5}{|c|}{ Baik } \\
\hline
\end{tabular}

Berdasarkan analisis ketercukupan komponen Scientific Approach dari keseluruhan RPP di SMP Muhammadiyah SeKecamatan Kalasan memperoleh persentase $88,21 \%$ termasuk kedalam kategori baik. Hasil evaluasi yang diperoleh dari perhitungan skor pada masing-masing komponen Scientific Approach untuk setiap indikator yang diamati meliputi kegiatan inti (mengamati, menanya, mengumpulkan informasi, mengasosiasikan / menalar, dan mengkomunikasikan).

\section{Pembahasan}

Menurut (Yusuf, 2015) menyatakan bahwa evaluasi adalah suatu usaha untuk mengukur dan sumber nilai secara objektif dari pencapaian hasil-hasil yang direncanakan sebelumnya, dimana hasil evaluasi tersebut dimaksudkan menjadi umpan balik untuk perencanaan yang akan dilakukan didepan. Tujuan evaluasi adalah untuk memperoleh informasi yang akurat dan objektif tentang suatu program.

Menurut (Permendikbud, 2016)bahwa Rencana Pelaksanaan Pembelajaran adalah rencana kegiatan pembelajaran tatap muka untuk satu pertemuan atau lebih. RPP dikembangkan dari silabus untuk mengarahkan kegiatan pembelajaran peserta didik dalam upaya mencapai Kompetensi Dasar (KD). Menurut (Zendrato, 2016) didalam penelitian mengatakan bahwa, ia menyadari begitu pentingnya RPP dalam pelaksanaan pembelajaran, setiap guru harus memiliki paradigma bahwa perencanaan pembelajaran adalah suatu hal yang wajib dilakukan sebelum mengajar di kelas. Guru perlu mengetahui bahwa RPP berisi garis besar (outline) apa yang akan dikerjakan oleh guru dan peserta didik selama proses pembelajaran. 
Rencana pelaksanaan pembelajaran yang digunakan yaitu kurikulum 2013 dengan menggunakan pendekatan Scientific Approach. Scientific Approach atau pendekatan ilmiah adalah proses pembelajaran yang dirancang sedemikian rupa agar peserta didik secara aktif mengkonstruksi konsep, hukum, atau prinsip melalui tahapantahapan mengamati (untuk mengidentifikasi atau menemukan masalah), merumuskan masalah, mengajukan atau merumuskan hipotesis, mengumpulkan data, menarik kesimpulan dan mengkomunikan konsep, hukum atau prinsip yang “ditemukan" (Daryanto, 2014).

Berdasarkan analisis data mengenai evaluasi rencana pelaksanaan pembelajaran berbasis Scientific Approach di SMP Muhammadiyah SeKecamatan Kalasan yaitu SMP Muhammadiyah 1 Kalasan dan SMP Muhammadiyah 2 Kalasan berada pada kategori baik. Kategori ini diperoleh berdasarkan analisa perhitungan nilai rata-rata dari teknik observasi RPP yang telah dibuat oleh guru IPA (Biologi). Hasil penelitian ini menunjukkan bahwa secara garis besar RPP yang telah disusun secara lengkap dan sistematis mencakup semua komponen-komponen RPP. Hal ini sejalan dengan penelitian (Puspitasari \& Aprilia, 2015) yang menyatakan bahwa hasil yang diperoleh dari evaluasi perencanaan proses pembelajaran yang menunjukkan hasil yang baik, karena RPP telah dibuat secara sistematis, komponen RPP yaitu standar kompetensi dan kompetensi dasar sudah sesuai dengan standar isi.

Komponen-komponen tersebut meliputi identitas sekolah, identitas mata pelajaran, kelas/semester, materi pokok, alokasi waktu, kompetensi inti, kompetensi dasar dan indikator pencapaian kompetensi, tujuan pembelajaran, materi pembelajaran, strategi dan metode pembelajaran, model pembelajaran, media pembelajaran, sumber belajar, langkah-langkah pembelajaran (kegiatan pendahuluan, kegiatan inti, dan kegiatan penutup), dan penilaian hasil pembelajaran.

Berdasarkan hasil analisis data terkait dengan ketercukupan komponen Scientific Approach di SMP Muhammadiyan SeKecamatan Kalasan mendapatkan nilai sebesar $88,21 \%$ sehingga masuk kedalam kategori baik, karena RPP yang diperoleh dari 2 sekolah di Kecamatan Kalasan ini memenuhi Komponen Scientific Approach pada setiap kegiatan inti yang ada didalam RPP tersebut. Komponen Scientific Approach terletak pada kegiatan inti yaitu mengamati, menanya, mengumpulkan informasi, mengasosiasikan/ menalar, dan mengkomunikasikan (Kemendikbud, 2013).

(Daryanto, 2014) menyebutkan bahwa metode mengamati sangat bermanfaat bagi pemenuhan ingin tahu siswa, sehingga proses pembelajaran memiliki kebermaknaan yang tinggi. Berdasarkan hasil analisis data ke-14 RPP didua sekolah, di SMP Muhammadiyah 1 Kalasan, pada RPP 1, 2, 3, 5, 6, 7 mendapatkan nilai sebesar $100 \%$, dan RPP 4 sebesar 83,33\% sehingga dikategorikan baik. Sedangkan di SMP Muhammadiyah 2 Kalasan, pada keseluruhan RPP mendapatkan nilai 100\% sehingga dikategorikan baik. Hal tersebut karena adanya objek yang harus diamati oleh peserta didik, memberikan kesempatan kepada peserta didik untuk melakukan pengamatan, melatih peserta didik untuk memperhatikan hal yang penting dari suatu objek, dan mengamati dengan indra (mencoba, mendengar, menyimak, melihat, menonton, dan sebagainya) dengan atau tanpa alat. Hal ini sejalan dengan penelitian (Wulandari, 2019) yaitu sebelum memulai pembelajaran, terlebih dahulu guru memfasilitasi peserta didik dengan menunjukkan media berupa gambar tentang materi perubahan lingkungan. Hal ini bertujuan 
untuk menarik minat dan menambah wawasan peserta didik.

(Daryanto, 2014), mengungkapkan bahwa guru yang efktif mampu menginspirasi siswa untuk meningkatkan dan mengembangkan ranah sikap, keterampilan, dan pengetahuannya. Pada saat guru bertanya, pada saat itu pula dia membimbing atau memandu siswa belajar dengan baik. Berdasarkan hasil analisis data ke-14 RPP didua sekolah, di SMP Muhammadiyah 1 Kalasan pada RPP 1 mendapatkan nilai sebesar 66,67\%, RPP 2, 3, 5, 6, 7 sebesar 75\% sehingga masuk kedalam kategori cukup. Hal ini sejalan dengan penelitian (Wulandari, 2019) yaitu guru memberi kesempatan kepada peserta didik untuk bertanya dengan baik. Peserta didik diperbolehkan bertanya hal-hal apapun yang ingin diketahui baik yang berkaitan dengan gambar ataupun hal-hal lain yang menjadi pengalaman peserta didik berkaitan dengan materi. Guru juga memberikan pertanyaan kepada peserta didik yang merangsang kemampuan berpikir. Namun ada satu RPP yaitu pada RPP 4 hanya mendapatkan nilai $25 \%$ sehingga dikategorikan tidak baik. Hal ini karena didalam RPP pada tahapan menanya tidak dicantumkan suatu pertanyaan dari hasil kegiatan

mengamati objek dalam pembelajaran, tidak memberikan kesempatan kepada peserta didik untuk bertanya mengenai apa yang sudah dilihat, disimak, dan dibaca, tidak ada kegiatan berdiskusi tentang informasi yang belum dipahami, informasi tambahan yang ingin diketahui, atau sebagai klarifikasi.

Menurut (Daryanto, 2014) bahwa aplikasi mengumpulkan data/mencoba/ eksperimen dimaksudkan untuk mengembangkan berbagai ranah tujuan belajar, yaitu sikap, keterampilan dan pengetahuan. Kegiatan ini merupakan tindak lanjut dari kegiatan menanya. Berdasarkan hasil analisis data ke-14 RPP didua sekolah, di SMP Muhammadiyah 1 Kalasan pada RPP 1, 4, 5, 7 mendapatkan nilai sebesar $100 \%$ sehingga dikategorikan baik. Hal ini sejalan dengan penelitian (Wulandari, 2019) yaitu Guru mengarahkan peserta didik untuk mencari dan membaca literatur dari berbagai sumber misalnya buku dan internet. Guru membimbing peserta didik memakai internet sesuai dengan kebutuhan informasi yang diinginkan. Peserta didik juga mencari literatur dari buku biologi yang didapat dari perpustakaan sekolah. RPP 2, dan 6 sebesar 75\%, RPP 3 sebesar 66,67\% sehingga masuk kedalam kategori cukup. Hal ini karena didalam kegiatan "mengumpulkan data" belum dilakukan kegiatan eksperimen terkait dengan materi dan belum megumpulkan data atau informasi dengan kelompok ataupun individu yang didampingi oleh guru. Berdasarkan hasil analisis RPP di SMP Muhammadiyah 2 Kalasan, untuk keseluruhan RPP pada bagian "mengumpulkan data" mendapatkan nilai $75 \%$ sehingga masuk kedalam kategori cukup. Hal tersebut karena belum mengumpulkan data/informasi melalui kegiatan eksperimen terkait materi, namun sudah mampu menggali dan mengumpulkan informasi dari berbagai sumber terkait materi, mencatat semua informasi yang didapatkan dengan tulisan yang rapi dan menggunakan Bahasa Indonesia yang baik dan benar, serta mengumpulkan informasi dengan kelompok ataupun individu yang didampingi guru.

(Daryanto, 2014) mengungkapkan bahwa kegiatan menalar adalah memproses informasi yang sudah dikumpulkan baik terbatas dari hasil kegiatan mengumpulkan informasi atau melakukan kegiatan eksperimen. Berdasarkan hasil analisis data ke14 RPP didua sekolah mendapatkan nilai sebesar $100 \%$ sehingga dikategorikan baik. Hal ini karena siswa memperoleh informasi untuk menemukan keterkaitan satu informasi dengan 
informasi lainnya, menemukan pola dari keterkaitan informasi, menganalisis data, mengasosiasi atau menghubungkan serta menambah keluasan dan kedalaman informasi.. Hal ini sejalan dengan penelitian (Utami, Zen, \& Madang, 2013) yaitu guru sudah seharusnya mencantumkan kegiatan mengolah dan menganalisis informasi yang sudah dikumpulkan, merangkum informasi yang dikumpulkan dari yang bersifat menambah keluasan dan mengumpulkan informasi tambahan.

(Daryanto, 2014) mengungkapkan bahwa kegiatan mengkomunikasikan dilakukan melalui kegiatan menuliskan atau menceritakan kembali apa yang ditemukan dalam kegiatan mencari informasi, mengasosiasikan dan menemukan pola. Berdasarkan hasil analisis data ke-14 RPP didua sekolah, di SMP Muhammadiyah 1 Kalasan pada RPP 1 mendapatkan nilai sebesar 100\%, RPP 3, dan 7 mendapatkan nilai 83,33\% sehingga masuk kedalam kategori baik. Namun, ada beberapa RPP yaitu RPP 2, 4, 5, dan 6 hanya mendapatkan nilai $50 \%$ dan masuk kedalam kategori kurang. Hal ini karena tidak adanya kegiatan menyajikan laporan dalam bentuk apapun meliputi hasil, proses, dan tidak menyampaikan hasil pengamatan, kesimpulan berdasarkan hasil analisis secara lisan, tertulis, atau media lainnya. Menurut (Yustyan, Widodo, \& Pantiwati, 2015) dalam penelitian nya menyebutkan bahwa kegiatan mengkomunikasin yaitu dengan mendiskusikan hasil kesimpulan yang telah dibuat bersama dan mempresentasikan secara lisan atau tanya jawab.

Berdasarkan hasil penelitian yang telah dilakukan, sejalan dengan dengan penelitian menurut (Nurfaizah, Farhan, \& Soewarno, 2017) yaitu penerapan pendekatan sanitifik/langkah ilmiah ini diterapkan untuk memberikan ruang lebih pada peserta didik dalam membangun kemandirian belajar serta mengoptimalkan potensi kecerdasan yang dimiliki. Pendekatan ini bertujuan untuk meningkatkan kemampuan intelek, khususnya kemampuan berfikir tingkat tinggi siswa, dan membentuk kemampuan siswa dalam menyelesaikan suatu masalah secara sistematis, serta menurut (Hidayati \& Endryansyah, 2014) Pendekatan ilmiah mampu meningkatkan kemampuan afektif siswa, hasil pengamatan menunjukkan bahwa kemampuan afektif siswa dapat ditingkatkan melalui pendekatan ilmiah. Hasil belajar ranah psikomotor menunjukkan bahwa pendekatan ilmiah mampu meningkatkan psikomotor siswa selama menjalani pembelajaran di kelas.

(Kunandar, 2013) melaksanakan program pada dasarnya mengimplementasikan program yang telah disusun dalam proses belajar mengajar di kelas. Hal ini berarti keberhasilan pelaksanaan pembelajaran sangat tergantung dari kualitas perencanaan pembelajaran yang telah disusun. Dengan perencanaan pembelajaran yang baik, akan menghasilkan pelaksanaan yang baik dan begitu juga sebaliknya.

\section{SIMPULAN}

Berdasarkan hasil dan pembahasan, dapat diperoleh kesimpulan penelitian yaitu persentase kesesuaian komponen rencana pelaksanaan pembelajaran (RPP) mata pelajaran IPA (Biologi) di SMP Muhammadiyah Se-Kecamatan Kalasan yang telah memenuhi komponen Permendikbud No.22 Tahun 2016 tentang Standar Proses sebesar 91,04\% menunjukkan kategori baik.

Persentase ketercukupan komponen Scientific Approach pada rencana pelaksanaan pembelajaran (RPP) mata pelajaran IPA (Biologi) di SMP Muhammadiyah Se-Kecamatan Kalasan sebesar 88,21\% menunjukkan kategori baik. 


\section{DAFTAR RUJUKAN}

Arikunto, S. (2010). Prosedur penelitian. Jakarta: Rineka Cipta.

Daryanto, D. (2014). Pendekatan pembelajaran saintifik kurikulum 2013. Yogyakarta: Penerbit Gava Media.

Hidayati, N., \& Endryansyah, E. (2014). Pengaruh Penggunaan Pendekatan Ilmiah (Scientific Approch) dalam Pembelajaran Terhadap Hasil Belajar Siswa Kelas XII TITL 1 SMK Negeri 7 Surabaya pada Standar Kompetensi Mengoperasikan Sistem Kendali Elektromagnetik. Jurnal Pendidikan Teknik Elektro, 3(2), 25-29. https://jurnalmahasiswa.unesa.ac.id/index .php/jurnalpendidikanteknikelektro/articl e/view/7498.

Hosnan, H. (2014). Pendekatan saintifik dan kontekstual dalam pembelajaran abad 21. Bogor: Ghalia Indonesia.

Ibrahim, R. (2010). Perencanaan pengajaran. Jakarta: Rineka Cipta.

Kemendikbud. (2013). Kerangka dasar kurikulum 2013. Jakarta: Kementerian Pendidikan dan Kebudayaan Direktorat Jenderal Pendidikan Dasar.

Kunandar, K. (2013). Penilaian autentik (penilaian hasil belajar peserta didik berdasarkan Kurikulum 2013). Jakarta: Raja Grafindo Persada.

Nurfaizah, N., Farhan, A., \& Soewarno, S. (2017). Pelaksanaan pendekatan scientific pada pembelajaran fisika di SMA Negeri di Kabupaten Pidie. Jurnal Ilmiah Mahasiswa (JIM) Pendidikan Fisika, 2(3),299-302.

http://www.jim.unsyiah.ac.id/pendidikan -fisika/article/view/5665/2331

Paraniti, A. A. I., \& Noviyanti, P. L. (2019). Evaluasi rencana pelaksanaan pembelajaran pada pelaksanaan PPL terhadap pemahaman mahasiswa dalam penerapan scientific approach. Jurnal Bakti Saraswati, 08(01), 1-9. http://ejournal.unmas.ac.id/index.php/bak tisaraswati/article/view/503.

Permendikbud. (2016). Standar Proses Pendidikan Dasar dan Menengah.

Puspitasari, D., \& Aprilia, N. (2015). Evaluasi perencanaan proses pembelajaran kontekstual pada mata pelajaran Biologi di SMP Negeri 1 Kalikajar Kabupaten Wonosobo. JUPEMASI-PBIO, 1(2), 188191.

https://www.researchgate.net/publication 1283506716 .

Shoimin, A. (2014). Model pembelajaran inovatif dalam kurikulum 2013. Yogyakarta: AR-RUZZ MEDIA.

Suciati, R., \& Astuti, Y. (2016). Analisis rencana pelaksanaan pembelajaran (RPP) mahasiswa calon guru Biologi. Journal Edusains,8(2),192-199.

https://doi.org/10.15408/es.v8i2.4059.

Sugiono, S. (2012). Metode penelitian kuantitatif, kualitatif, dan $R \& D$. Bandung: Alfabeta.

Sukardi, S. (2011). Metodologi penelitian pendidikan kompetensi dan praktiknya. Yogyakarta: Bumi Aksara.

Susilo, M. J. (2016). Pembelajaran IPA Biologi berbasis scientific approach di SMP Muhammadiyah 2 Depok Sleman. Proceeding Biology Education Conference, 13(1), 97-101. https://jurnal.uns.ac.id/prosbi/article/view 15666 .

Utami, W., Zen, D., \& Madang, K. (2013). Analisis Kesesuaian Langkah-Langkah Pembelajaran Pada Rencana Pelaksanaan Pembelajaran. Jurnal Pembelajaran Biologi, 2(1), 83-95.

Warso, A. W. D. D. (2014). Proses pembelajaran dan penilaian di satuan pendidikan. Klaten: CV. Sahabat.

Wulandari, D. (2019). Evaluasi pelaksanaan pembelajaran Biologi berbasis scientific approach pada materi perubahan lingkungan siswa kelas X MIA di SMA Negeri Se Kecamatan Ngaglik 
(Universitas Ahmad Dahlan).

http://eprints.uad.ac.id/14832/.

Yustyan, S., Widodo, N., \& Pantiwati, Y. (2015). Peningkatan kemampuan berpikir kritis dengan pembelajaran berbasis scientific approach siswa kelas X SMA Panjura Malang. Jurnal Pendidikan Biologi Indonesia, 1(2), 240-254. https://doi.org/https://doi.org/10.22219/jp bi.v1i2.3335.

Yusuf, M. (2015). Asesmen dan evaluasi pendidikan. Jakarta: Kencana.

Zendrato, J. (2016). Tingkat penerapan rencana pelaksanaan pembelajaran dalam pelaksanaan pembelajaran di kelas suatu studi kasus di SMA Dian Harapan Jakarta. Scholaria: Jurnal Pendidikan Dan Kebudayaan, 6(2), 58-73. https://doi.org/10.24246/j.scholaria.2016. v6.i2.p58-73. 